\title{
Alcohol and nutrition
}

By Marsha Y. Morgan and James A. Levine, Academic Department of Medicine, Royal Free Hospital and School of Medicine, Pond Street, Hampstead, London NW3 2QG

Chronic alcoholics are often malnourished. The aetiology is multifactorial. The relation between malnutrition and tissue injury remains in debate as it is often difficult to separate the effects from those of alcohol per se. Patients' susceptibility to tissue injury varies and this will modify the effects of both alcohol and malnutrition. Difficulty arises in relating nutritional status at any point in time with the presence of tissue injury that has often taken years to develop. Nevertheless, nutritional deficiencies should be identified and corrected in order to limit further damage and to facilitate repair.

\section{Evidence and incidence of malnutrition in alcoholics}

A number of difficulties arise in trying to evaluate the incidence of malnutrition in alcoholic patients. It is widely assumed that the majority of individuals who abuse alcohol are malnourished. However, most of the studies on which these observations are based tend to focus on unrepresentative populations of derelict, often physically-ill alcoholics (Olsen, 1950; Patek et al. 1975) or else deduce information on overall nutritional status from single nutrient deficiencies (Minot et al. 1933; Frank et al. 1971). There is evidence to suggest that frank deficiency disease is uncommon in alcoholic individuals (Bean $e t$ al. 1949; Camilo et al. 1981) and that when present malnutrition is only mild to moderate in degree (Neville et al. 1968; Morgan, 1981). Nevertheless, these studies have been largely ignored. Thus, the extent to which the findings of the early, often quoted studies remain representative of the majority of chronic alcoholics today is debatable.

Very few anthropometric studies have been undertaken primarily in alcoholic populations; those that are available are often incomplete (Table 1). The results of these various studies indicate that in general, alcoholic individuals maintain body-weight. However, in the majority of studies, $30 \%$ or more of the individuals surveyed showed a reduction of lean body mass, whilst $50 \%$ or more showed reduced fat stores. Overall the

Table 1. Incidence of anthropometric abnormalities (percentage abnormal) in individuals abusing alcohol

\begin{tabular}{|c|c|c|c|c|c|c|c|c|}
\hline Reference & $n$ & $\begin{array}{l}\text { Liver } \\
\text { disease }\end{array}$ & Wtht & TSF & MAC & MAMC & $\mathrm{Cr}_{\mathrm{r}} / \mathrm{ht}$ & Albumin \\
\hline Bistrian et al. (1976) & 52 & ? & 31 & 75 & - & so & - & - \\
\hline O'Keefe et al. (1980) & 32 & $\begin{array}{c}? \\
\text { Cirrhosis }\end{array}$ & 6 & 55 & - & - & - & - \\
\hline $\begin{array}{l}\text { Morgan et al. (1981) } \\
\text { Camilo \& Pinto Correia }\end{array}$ & 55 & $\begin{array}{c}33 \% \\
\text { Cirrhosis }\end{array}$ & 7 & 51 & 33 & 29 & 40 & 18 \\
\hline$(1982)$ & 103 & $70 \%$ & 41 & 64 & - & 55 & - & 59 \\
\hline Mills et al. (1983) & 30 & $\begin{array}{c}? \\
\text { Hepatitis } \pm \\
\text { cirrhosis }\end{array}$ & - & 107 & - & 90 & - & - \\
\hline Mendenhall et al. (1984) & 284 & $100 \%$ & 63 & 86 & - & 52 & 85 & 71 \\
\hline
\end{tabular}

Wtht, weight/height; TSF, triceps skinfold thickness; MAC, mid-arm circumference; MAMC, mid-arm muscle circumference; $\mathrm{Cr} / \mathrm{ht}$, creatinine/height. 
incidence of anthropometric abnormalities in alcoholic patients, as represented by the studies detailed, is no greater than in surveys of general medical and surgical patients (Bistrian et al. 1976; Blackburn et al. 1977) in which $44-50 \%$ of the patients show anthropometric abnormalities.

In a number of studies sufficient details of the patient populations were given to enable the relation between nutritional status, judged clinically and anthropometrically, and the severity of alcohol-related liver injury to be explored. In patients with well-compensated liver disease (Morgan, 1981; Mills et al. 1983), the incidence of malnutrition was independent of the presence of cirrhosis (Fig. 1). However, in patients with decompensated liver disease (Camilo \& Pinto Correia, 1982; Mendenhall et al. 1984) the incidence of malnutrition increased with increasing severity of liver injury (Fig. 2).

Much more information is available regarding the incidence of vitamin and mineral deficiencies in alcoholic individuals (Table 2). However, a number of problems also arise in the interpretation of this information. Thus, the patient populations studied often vary considerably, both in terms of their social circumstances and physical status. In the majority of studies very little information is provided regarding recent drinking behaviour and no attempt has been made to standardize the timing of sample collection. The methods available for assessing vitamin status are often indirect and several different assay procedures may have been used. Values designated 'low' or 'deficient' are often arbitrarily defined and the 'cut-off' points tend to vary from study to study. Finally, while

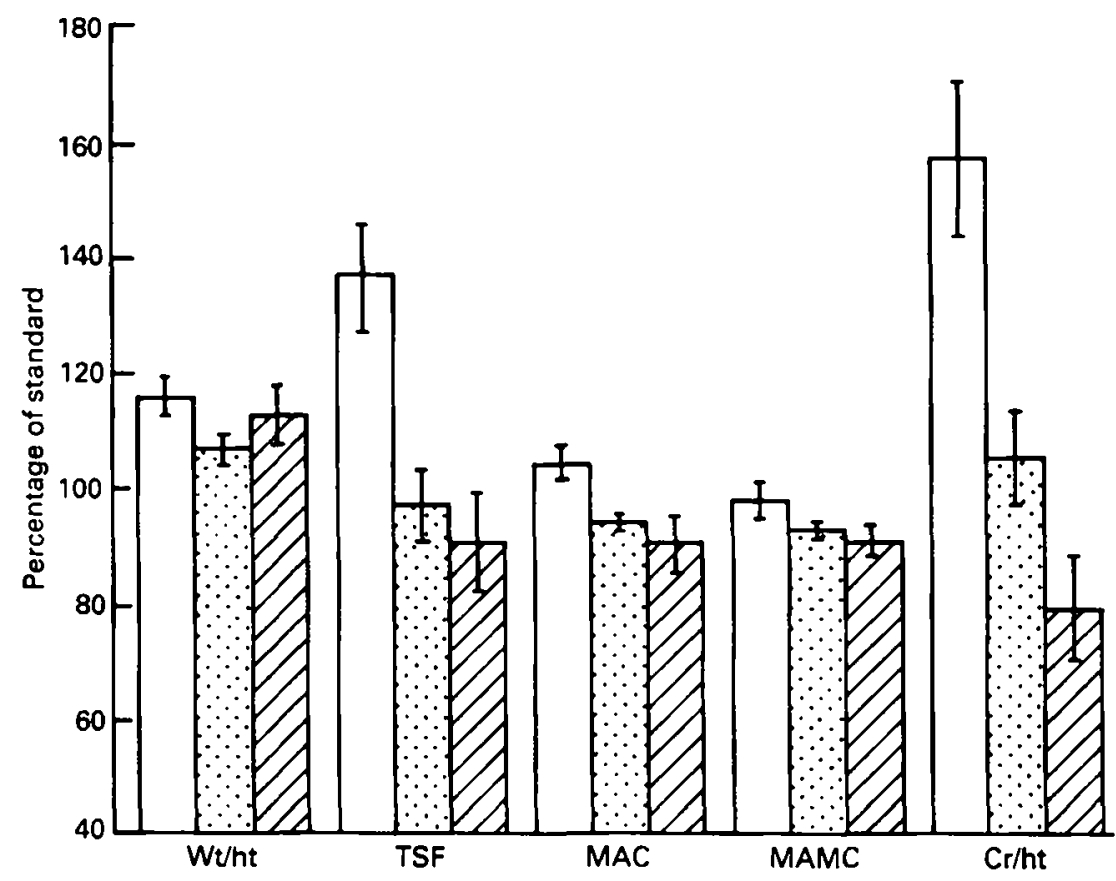

Fig. 1. Antropometric measures expressed as a percentage of standard values in control subjects $(\square, n 20)$ and in alcoholic patients with non-cirrhotic liver damage (国, $n 37$ ) and cirrhosis (国, $n 18$ ). Values are means with their standard errors represented by vertical bars. Weight/height $(\mathrm{Wt} / \mathrm{ht})$, triceps skinfold thickness (TSF), mid-arm circumference (MAC), mid-arm muscle circumference (MAMC), creatinine/height index (Cr/ht). Adapted from Morgan (1981). 


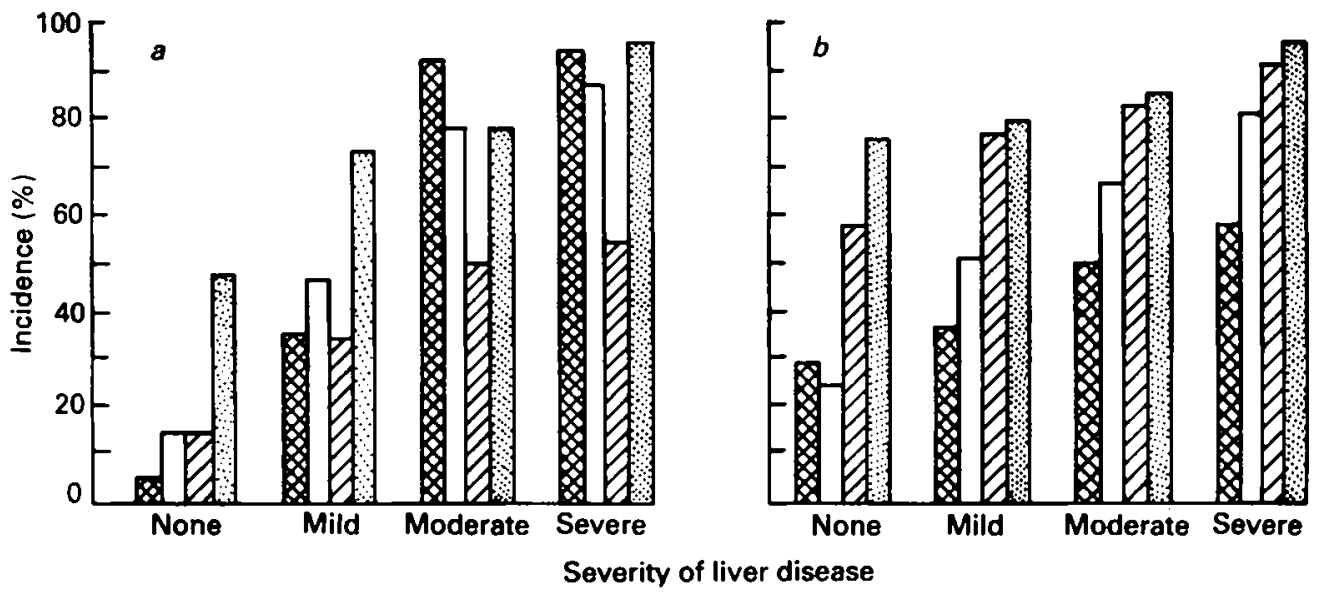

Fig. 2 Percentage of alcoholic patients showing abnormalities of measured variables in relation to the presence and severity of their liver disease. (a) Kwashiorkor-like: (因), plasma albumin; ( $\square$ ), plasma transferrin: (Z), lymphocyte count; (国), skin anergy. (b) Marasmus-like: (B), mid-arm muscle circumference; $(\square)$, percentage ideal body-weight; ( $(\mathbb{B})$, creatinine/height index; ()), triceps skinfold thickness. Adapted from Mendenhall et al. (1984).

Table 2. Incidence of vitamin and mineral deficiencies in individuals abusing alcohol

\begin{tabular}{|c|c|c|}
\hline $\begin{array}{l}\text { Vitamin or } \\
\text { mineral }\end{array}$ & $\begin{array}{c}\text { Incidence of } \\
\text { deficiency }(\%)\end{array}$ & Comment \\
\hline Thiamin & $9-80$ & $\begin{array}{l}\text { Association with Wernicke-Korsakoff syndrome. } \\
\text { Clinical symptoms: rare. } \\
\text { Variation due to: methodology and population differences. } \\
\text { Causative factors: decreased dietary intake, impaired } \\
\text { phosphorylation, impaired metabolism, decreased storage. }\end{array}$ \\
\hline Riboflavin & $15-50$ & $\begin{array}{l}\text { Clinical symptoms: rare. } \\
\text { Causative factor: decreased dietary intake. }\end{array}$ \\
\hline Niacin & $?$ & $\begin{array}{l}\text { Pellagra in industrialized countries is often associated with alcohol } \\
\text { abuse. } \\
\text { Reduced hepatic levels in alcoholics. } \\
\text { Causative factors: decreased dietary intake, decreased conversion to } \\
\text { active forms, increased requirement, decreased storage. }\end{array}$ \\
\hline Pyridoxine & $?$ & Causative factor: primarily increased degradation. \\
\hline Folic acid & $6-87$ & $\begin{array}{l}\text { Causative factors: decreased food intake, malabsorption, } \\
\text { decreased hepatic retention, altered enterohepatic recycling. }\end{array}$ \\
\hline Vitamin $B_{12}$ & None & \\
\hline Pantothenic acid & $?$ & Associated with severity of liver disease. \\
\hline Biotin & ? & \\
\hline Ascorbic acid & $30-50$ & Causative factor: decreased food intake. \\
\hline Vitamin A & $?$ & $\begin{array}{l}\text { Ethanol inhibits retinal formation. } \\
\text { Low hepatic levels. }\end{array}$ \\
\hline Vitamin D & ? & $\begin{array}{l}\text { Low plasma levels. } \\
\text { Causative factor: malabsorption. }\end{array}$ \\
\hline Vitamin E & ? & $\begin{array}{l}\text { Causative factors: decreased dietary intake, impaired hepatic } \\
\text { synthesis. }\end{array}$ \\
\hline Magnesium & $?$ & Clinical signs may be present. \\
\hline Zinc & $?$ & $\begin{array}{l}\text { Low plasma levels. } \\
\text { Causative factors: decreased dietary intake, increased excretion. }\end{array}$ \\
\hline
\end{tabular}


it is generally believed that subnormal vitamin and mineral levels may be deleterious, there is rarely evidence to support this contention. A high percentage of alcoholic individuals show 'subclinical' or 'deficient' circulating concentrations of vitamins and minerals. However, the incidence of clinically overt deficiency disease is low.

\section{Aetiology of malnutrition}

\section{DIETARY INTAKE}

The energy value of alcohol is $29.7 \mathrm{~kJ}(7.1 \mathrm{kcal}) / \mathrm{g}$, so that a standard bottle of $70^{\circ}$ proof spirit will provide $7113 \mathrm{~kJ}(1700 \mathrm{kcal})$, which is about half the recommended daily energy requirement for a normal adult.

Alcohol does not, however, provide equivalent energy food value compared with other energy sources and alcoholic beverages contain only small amounts of other nutrients inadequate to meet daily requirements. Pirola \& Lieber (1972) substituted alcohol isoenergetically for carbohydrate in the diets given to eleven healthy subjects, and recorded weight loss. In a single individual they supplemented a basic $9200 \mathrm{~kJ}(2200$ kcal) diet with $8370 \mathrm{~kJ}$ (2000 kcal) either as chocolate or as alcohol and noted significantly less weight gain during alcohol feeding (Fig. 3). Crouse \& Grundy (1984) showed that non-obese subjects given $2636 \mathrm{~kJ}$ (630 kcal) ethanol/d lost weight, whereas obese subjects given the same supplement gained weight.

When alcohol is taken chronically, the activity of the microsomal ethanol-oxidizing system in the liver is induced and its contribution to ethanol metabolism increases. The existence and induction of this pathway for ethanol metabolism may explain, at least in part, the weight loss observed in individuals actively abusing alcohol (Roggin et al. 1969; World $e$ t al. 1984) and the fact that ethanol produces a greater increase in oxygen consumption in chronic alcoholics than in control subjects (Higgins, 1917; Stock \& Stuart, 1974).

Many early studies reported that alcoholics take grossly deficient diets and suggested that poor dietary intake was the principal cause of nutritional deficiencies in these patients. Most of these early studies, however, reported on alcoholics with liver disease and with very poor socio-economic backgrounds (Leevy et al. 1965; Patek et al. 1975).

More recent studies, undertaken in middle-class alcoholic individuals, free from major complicating disease (Neville et al. 1968; Morgan, 1981), suggest that diets may be
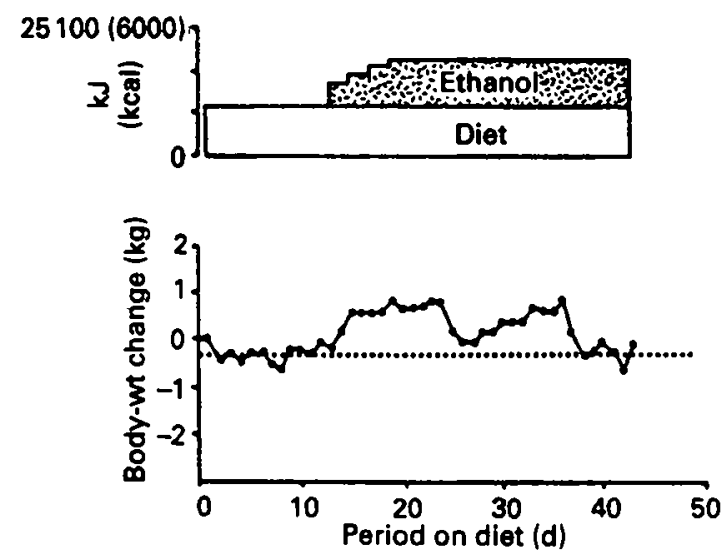
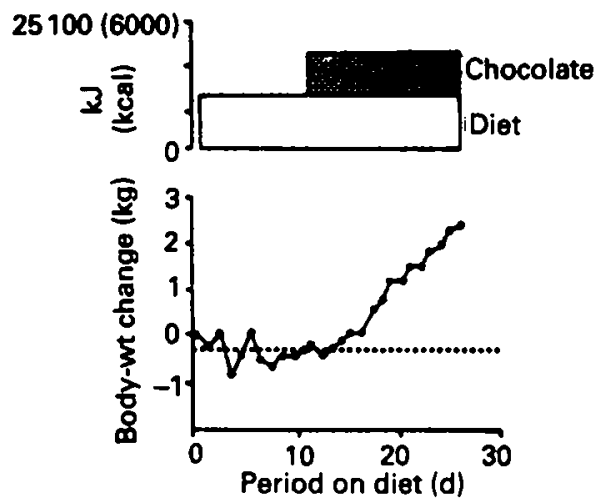

Fig. 3. (a) The effects on body-weight of adding $8370 \mathrm{~kJ}(2000 \mathrm{kcal}) / \mathrm{d}$ as ethanol to the diet of one subject. $(\ldots$.$) , Mean weight change during the control period. (b) The effect on body-weight of adding 8370 \mathrm{~kJ}$ (2000 $\mathrm{kcal}) / \mathrm{d}$ as chocolate to the diet of the same subject. (....), Mean change during the control period.

Adapted from Pirola \& Lieber (1972). 
adequate in terms of the quantity of individual nutrients taken, but are often grossly imbalanced. These patients appeared to add alcohol to their diet rather than substituting or exchanging it for items of food. In this respect, they behave similarly to normal individuals, who on days when they consume alcohol tend not to change or may even increase the amounts of dietary protein, fat and carbohydrate they ingest (Bebb et al. 1971).

Two major conceptual problems arise in considering the role of dietary intake in the genesis of malnutrition in individuals consuming excessive quantities of alcohol. First, little or no accurate information is available about dietary habits during the early years of drinking. Second, the assessment of the adequacy of the diet is based on values for ideal body-weight and recommended daily allowances for healthy control populations. Very little information is available on the optimum nutrient requirements for individuals consuming up to $50 \%$ of their energy as alcohol, or on the requirements of patients with liver disease. It has been shown that resting energy requirements are increased in alcoholics free of liver disease (Jhangiani $e t$ al. 1985) but that individuals with alcoholic cirrhosis have basal energy requirements similar to those of healthy non-alcoholics (Owen et al. 1981, 1983). Following an overnight fast, however, individuals with alcoholic cirrhosis show a pattern of fuel utilization indicative of relative carbohydrate sparing which is similar to that observed in healthy subjects after a $3 \mathrm{~d}$ fast (Owen et al. 1983). These patients therefore enter a state of catabolism more readily than normal subjects.

\section{MALDIGESTION AND MALABSORPTION}

Impairment of intestinal absorption has been documented in approximately $50 \%$ of hospitalized alcoholics (Baraona et al. 1962; Mezey et al. 1970). Alterations in the intestinal absorption of nutrients can be attributed to a direct effect of alcohol. However, the situation is complicated because of changes in absorption caused by malnutrition and as a consequence of alcohol-related pancreatic and liver disease.

Alcoholics frequently complain of non-specific digestive disorders such as anorexia, nausea, epigastric discomfort, flatulence and diarrhoea (Morgan \& Sherlock, 1977; Wilson \& Hoyumpa, 1979). Symptoms generally disappear after a period of hospitalization and abstinence from alcohol (Halsted et al. 1971). No correlation exists, however, between the presence of intestinal symptoms and impairment of absorptive function.

Evidence of malabsorption. Steatorrhoea has been reported in $35-56 \%$ of alcoholics who have been drinking recently. However, the increase in fat excretion is usually mild (Small et al. 1959; Krasner et al. 1976). Alcohol in modest doses will interfere with the absorption of L-methionine (Israel et al. 1969) and 16-76\% of alcoholics show evidence of D-xylose malabsorption (Small et al. 1959; Krasner et al. 1976). Intestinal absorption of sodium and chloride ions and water is significantly reduced in individuals chronically abusing alcohol (Krasner et al. 1974) and the absorption of several water-soluble vitamins is impaired, notably thiamin (Tomasulo et al. 1968; Thomson et al. 1970), folic acid (Halsted et al. 1973) and vitamin $B_{12}$ (Lindenbaum \& Lieber, 1969). There is poor correlation between evidence of malabsorption of one substance with that of another (Mezey et al. 1970), as might be expected, as several mechanisms exist for the absorption of nutrients, not all of which are affected by alcohol.

Mechanisms of malabsorption (Table 3). (1) Direct effects of alcohol. Alcohol has direct effects on gastric emptying, small intestinal motility, structure and function, pancreatic and biliary secretion and splanchnic bloot and lymph flow.

The effects of alcohol on gastric emptying vary depending on the concentration and form in which the alcohol is given, the route by which it is administered and the timing of 


\section{Table 3. Mechanisms of malabsorption}

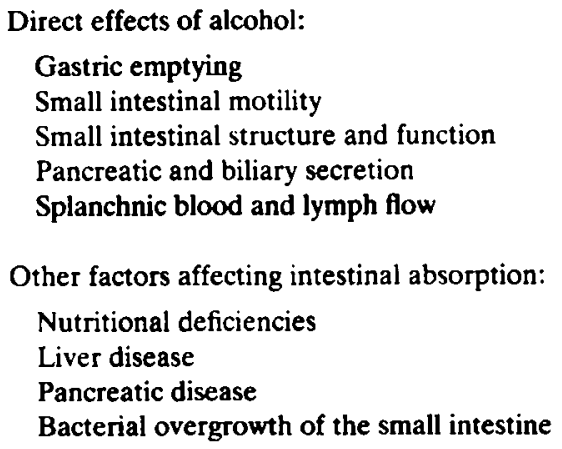

administration in relation to food. Alcohol in concentrations of $80-100 \mathrm{~g} / \mathrm{l}$ either has no effect on gastric emptying (Barlow et al. 1936) or else accelerates it (Harichaux et al. 1971), whereas alcohol in higher concentrations inhibits gastric emptying (Barboriak \& Meade, 1970; Cooke, 1972). These effects of alcohol on gastric emptying have been attributed to its hyperosmolarity (Iber, 1971), a direct effect of alcohol on gastric muscle (Harichaux et al. 1971), the effects of alcohol on central control mechanisms (Tennent, 1941) or to local neural irritation (Cooke, 1972). The method used to estimate gastric emptying and the drinking behaviour of the individuals studied also influences the results. The congeners in alcoholic beverages may have separate or additional effects (Greenberg, 1970).

Alcohol given intravenously increases motility in the second part of the duodenum (Pirola \& Davis, 1970), decreases impeding Type I wave activity in the jejunum and increases Type I wave activity in the ileum (Robles et al. 1974). The net effect is likely to be accelerated small intestinal transit which might explain, at least in part, the occurrence of diarrhoea following binge drinking (Small et al. 1959; Iber, 1971).

Haemorrhagic lesions in the villous tips of the duodenum have been observed in human volunteers after ingestion of alcohol at a dose of $1 \mathrm{~g} / \mathrm{kg}$ body-weight (Gottfried et al. 1976). A significant reduction in the activity of jejunal glycolytic and gluconeogenic enzymes has been observed in volunteers given moderate doses of alcohol (Owen et al. 1983). Chronic ethanol feeding produces little or no gross change in the small intestine in chronic alcoholics recently abstinent, but produces characteristic ultrastructural abnormalities in the intestinal epithelial cells such as swelling of mitochondria, dilatation of the smooth endoplasmic reticulum and a reduction in ribosomes (Rubin et al. 1972). In general alcohol either has no effect or enhances the passive transport of nutrients through the intestinal wall, although it may inhibit the absorption of several actively transported substances such as glucose (Chang et al. 1967), amino acids (Chang \& Glazko, 1975), water and electrolytes (Mekhjian \& May, 1977) and thiamin (Hoyumpa et al. 1975), probably as a result of inhibition of membrane-bound $\mathrm{Na}^{+}, \mathrm{K}^{+}-\mathrm{ATPase}$ activity. The change in $\mathrm{Na}^{+}, \mathrm{K}^{+}$-ATPase activity might reflect the effects of ethanol on enterocyte membrane viscosity and lipid composition (Gray et al. 1980).

Alcohol increases small intestinal permeability to macromolecules (Chowdhury et al. 1977) which might provide a portal for the entry of toxic molecules. In addition, protein-losing enteropathy might be an important case of protein malnutrition in chronic alcoholics (Bretagne et al. 1982).

Intravenous alcohol inhibits pancreatic exocrine secretion in non-alcoholic subjects 
(Mott et al. 1972); pancreatic exocrine insufficiency has been noted in chronic alcoholics. Pancreatic function returns to normal with abstinence from alcohol in the absence of chronic pancreatitis (Mezey et al. 1970).

In man, hepatic blood flow has been shown to increase following relatively modest doses of alcohol by some workers (Mendeloff $e t$ al. 1949) whilst others have reported no effect (Castenfors et al. 1960). An increase in hepatic blood flow might facilitate passive diffusion of certain nutrients through the intestinal mucosa, although active transport is unlikely to be affected (Varro et al. 1967). In animals, ethanol enhances intestinal lymph flow, an effect associated with an increased output of both dietary lipids and plasma proteins into the lymph stream (Baraona \& Lieber, 1975).

(2) Other factors affecting intestinal absorption. Nutritional deficiencies can adversely affect both intestinal and pancreatic function. Folate deficiency is associated with impaired intestinal absorption in alcoholic and non-alcoholic subjects (Hift \& Adams, 1963). Malabsorption of folic acid, xylose and glucose can be demonstrated in subjects given ethanol and a diet deficient in folic acid. These abnormalities reverse if folic acid supplements are given, even if alcohol is continued (Halsted et al. 1973). Severe protein malnutrition results in structural and functional alterations of the small intestine (Mayoral et al. 1967) and pancreas (Davies \& Brist, 1948). Recovery occurs when high-protein diets are given. The abnormalities of pancreatic exocrine function seen in chronic alcoholics which improve following hospitalization have been attributed to subclinical protein malnutrition (Mezey et al. 1970).

Steatorrhoea occurs in approximately $50 \%$ of patients with alcoholic cirrhosis (Fast et al. 1959; Losowsky \& Walker, 1969) and in a similar percentage of patients with non-alcoholic, chronic liver disease (Morgan et al. 1976). Several factors may contribute to the steatorrhoea such as abnormal pancreatic function (Stinson et al. 1952; Arky, 1971), decreased intralumen concentrations of conjugated bile salts (Badley et al. 1970), decreased bile salt synthesis and impaired biliary excretion of bile salts (Vlahcevic et al. 1971), lymphatic hypertension (Dumont \& Mulholland, 1962), and neomycin administration (Marin et al. 1969).

The bacterial flora of the jejunum in alcoholics differs significantly from that seen in non-alcoholic controls (Bode et al. 1980). This may produce functional disturbances of the small intestine.

\section{IMPAIRED NUTRIENT METABOLISM}

The effects of chronic alcohol ingestion on metabolism are wide-ranging. Ethanol inhibits albumin synthesis (Rothschild et al. 1969), impedes protein release from the liver (Baraona et al. 1977), inhibits gluconeogenesis (Arky \& Freinkel, 1969) and impairs vitamin utilization. Alcohol may interfere with the conversion of thiamin to its active form (Camilo et al. 1981) and also interferes with the hepatic formation and release of 5-methyltetrahydrofolic acid, the principal circulating form of folate, which is also the folate co-enzyme necessary for DNA synthesis (Paine et al. 1973). Similarly, ethanol interferes with the conversion of pyridoxine to its active form, the co-enzyme pyridoxal5-phosphate (Hines, 1969).

\section{DECREASED HEPATIC STORAGE}

Alcoholics with fatty liver show reduced hepatic concentrations of folate, riboflavin, nicotinamide, pantothenic acid, pyridoxine, vitamin $B_{12}$, thiamin and vitamin $A$ (Frank et al. 1971). Similar reductions in hepatic vitamin stores are seen in patients with alcoholic cirrhosis although their thiamin stores tend to be normal (Baker et al. 1964). In addition, the uptake of folic acid and vitamin $B_{12}$ by the liver may be reduced in these 
patients (Glass \& Mersheimer, 1960) and the release of vitamins from hepatic stores may be increased (Waters et al. 1966).

\section{INCREASED REQUIREMENTS OF NUTRIENTS}

Weight gain is significantly lower when alcohol is consumed rather than isoenergetic amounts of carbohydrate (Pirola \& Lieber, 1972), suggesting that the body's energy requirements may increase during alcohol consumption. Increased requirements for certain vitamins, particularly those required for tissue repair such as folic acid, pyridoxine and vitamin $B_{12}$, have been documented in alcoholic individuals (Leevy et al. 1971). Increased requirements for haematinics may occur as the result of gastrointestinal bleeding, hypersplenism, haemolysis and infection (Klipstein \& Lindenbaum, 1965).

\section{INCREASED URINARY AND FAECAL LOSSES}

High faecal nitrogen concentrations have been reported in chronic alcoholics (Roggin et al. 1969). Increased urinary losses of zinc (Mills et al. 1983), calcium, magnesium and phosphate (Kalbfleisch et al. 1963; McDonald \& Margen, 1979) have been reported following alcohol ingestion.

\section{Relation of malnutrition to tissue injury}

The relation between malnutrition and tissue injury seen in individuals abusing alcohol remains in doubt. Thus, Leevy et al. (1971) showed that a high percentage of alcoholic patients with low circulating vitamin concentrations had no clinical stigmata of deficiency. On the other hand, profound clinical evidence of vitamin deficiency may be encountered in patients in whom vitamin levels are only marginally reduced (Dastur et al. 1976). More recently it has been suggested that malnutrition might have important effects at a subcellular level which are neither readily observed nor quantified. Indeed chronic alcoholics rendered folate-, pyridoxine- or vitamin $B_{12}$-deficient show defective incorporation of nucleic acid precursors into DNA/RNA and significantly impaired DNA synthesis and cell replication (Leevy \& Zetterman, 1975). While malnutrition may not be the initiating factor in the tissue injury seen in these patients, deficiencies should be corrected in order to limit and repair damage.

\section{LIVER}

Information is available from several early inpatient studies, in which alcohol was given to patients with alcohol-related liver disease, together with a well-balanced diet, which suggests that alcohol in doses of up to $300 \mathrm{~g}$ daily does not impede recovery from alcohol-related liver injury (Patek \& Post, 1941; Reynolds et al. 1965). Conversely it has been shown that alcohol can exert a direct hepatotoxic effect independently of dietary intake in both alcoholic patients and non-alcoholic volunteers (Lieber et al. 1965; Rubin \& Lieber, 1968).

The relative importance of malnutrition and alcohol toxicity in the pathogenesis of alcohol-related liver damage has been debated for years. It is probable that the initial injury reflects the toxicity of alcohol or one of its metabolites but that the patient's nutritional status may determine the extent of the damage and the degree of repair.

\section{CARDIOVASCULAR SYSTEM}

Cardiac dilatation, hypertrophy and congestive heart failure have been reported in chronic alcohol users (Wood, 1855). Initially these findings were attributed to nutritional deficiencies (Bollinger, 1884). However, evidence began to accumulate which suggested that ethanol itself might adversely affect cardiac structure and function (Weishaar et al. 
1977). As a result of this study and many more it now seems clear, and is generally accepted, that alcohol can have significant deleterious effects on the heart. An occasional alcoholic may still develop heart disease as a consequence of thiamin deficiency, although such individuals are encountered only rarely in clinical practice in the Western World. In the mid-1960s, a number of beer drinkers developed a relatively acute, fulminating cardiomyopathy thought to be due to the cobalt chloride added to the beer as a foam stabilizer (Kesteloot et al. 1968).

\section{BLOOD, BONE MARROW AND IMMUNE SYSTEM}

Alcoholic individuals show a large number of haematological abnormalities (Whitehead et al. 1978), a proportion of which are directly related to nutritional deficiencies. Megaloblastic anaemia is commonly encountered in hospitalized, malnourished, alcoholic patients (Eichner \& Hillman, 1971) and is almost invariably associated with folic acid deficiency. Severe folate deficiency is associated with pancytopaenia which will resolve with abstinence from alcohol together with a nutritious diet, without need for additional folate supplements (Eichner \& Hillman, 1971).

Florid sideroblastic changes in bone marrow are only encountered in alcoholic patients who are also malnourished (Hines, 1969). These abnormalities probably arise as a result of a defect in haem synthesis secondary to pyridoxine deficiency. Sideroblastic marrow changes can be produced in volunteers given ethanol together with a diet deficient in pyridoxine and folic acid. The marrow reverts to normal after treatment with pyridoxal5-phosphate alone, despite continued alcohol abuse.

Alcoholic patients are highly susceptible to infection, which may relate in part to their decreased marrow granulocyte reserves. These reduced reserves may be related to folate deficiency and possibly also to copper deficiency (Dunlop et al. 1974). Zn deficiency is associated with impaired cell-mediated immunity and increased susceptibility to infection (Fernandes et al. 1979).

Thrombocytopaenia is common in the drinking alcoholic and while it is predominantly directly alcohol-related it may also be associated with severe folate deficiency.

\section{NERVOUS SYSTEM}

Alcohol has profound, direct toxic effects on the central and peripheral nervous systems. In addition chronic alcoholics exhibit a number of neurological disorders which are related to nutritional deficiencies (Victor \& Adams, 1961). Vitamin deficiencies are of particular importance especially thiamin, nicotinic acid, pyridoxine and vitamin $B_{12}$, all of which are essential for normal cerebral functioning (Mcllwain \& Bachelard, 1971). Marginal deficiencies produce alterations in behaviour whilst more severe deprivation, over a period of time, may produce irreversible, structural cerebral changes.

Thiamin deficiency occurs in $\mathbf{9 - 8 0 \%}$ of individuals consuming excessive amounts of alcohol, and in a percentage of these its presence is complicated by the development of the Wernicke-Korsakoff syndrome (Hell \& Six, 1977). Nicotinic acid and pyridoxine deficiency can produce behavioural changes and psychiatric disturbances.

A mixed motor-sensory peripheral neuropathy is often found in chronic alcoholics (Morgan \& Sherlock, 1977). Deficiencies of thiamin, nicotinic acid, pantothenic acid, pyridoxine, riboflavin or phosphorus may be causally related. Often more than one deficiency is present.

\section{Nutritional assessment}

A variety of techniques have been used to assess nutritional status, although no one method provides all the necessary information. In practice, nutritional status is best 
assessed by combining the results of the nutritional history, physical examination, anthropometric measurements and selected laboratory analyses.

Particular difficulties may be encountered in assessing nutritional status in alcoholic individuals with or without liver disease. First, too much reliance should not be placed on weight, or weight:height ratio as a routine measure of metabolic status, since weight is only a useful indicator of nutritional status when lean body mass is decreased; in patients with fluid retention its measurement is misleading. Second, interpretation of the biochemical and immunological findings used to assess visceral protein status may be difficult because alcohol may impair hepatic protein synthesis leading to a reduction in circulating plasma proteins and may induce lymphopaenia and cutaneous anergy; these changes are exaggerated in individuals with associated alcohol-related liver disease.

\section{Management}

The mainstays of nutritional therapy in alcoholic individuals free of complicating physical disease and without overt malnutrition are withdrawal of alcohol and the provision of a well-balanced diet. It has been suggested that when alcohol is withdrawn the lost energy should be replaced by other nutrients. However, isoenergetic substitution would probably be inappropriate as the energy from alcohol is not fully utilized. At present the information is not available to enable appropriate substitutions to be made. In practice, therefore, these patients are given high-energy, high-protein diets. As individuals who abuse alcohol are often vitamin deficient, there is a reasonable therapeutic basis for routine vitamin supplementation. It is expensive and time-consuming to investigate for vitamin deficiencies, whereas multivitamin therapy is cheap and is generally harmless, if recommended doses are not exceeded.

Much greater difficulty arises in providing a rational nutritional regimen for alcoholic individuals who are malnourished and who may, in addition, have alcohol-related liver disease. These patients should take a diet which provides adequate intakes of energy, protein, vitamins and minerals. However, it is likely that a diet which is adequate for a normal healthy individual may not be adequate in the presence of liver disease.

Many alcoholic individuals are anorexic or suffer from nausea or abdominal discomfort. Maintenance of an adequate oral intake may prove difficult under these circumstances. If a reasonable dietary intake can be achieved and body-weight is maintained, nothing further is required. Unfortunately, it is often difficult to sustain adequate oral intake in patients with persistent anorexia and nausea, or to increase oral intake beyond a certain limit in malnourished patients. Diets can be homogenized and taken in liquid form, but it is preferable to continue oral food intake and to make up any deficit with supplemental feeds. Approximately $840 \mathrm{~kJ}$ (200 kcal) should be provided for each gram $\mathrm{N}$ given, $40 \%$ from fat and $60 \%$ from carbohydrate. Malnourished patients, particularly those who have taken an inadequate diet for some time, often find that even small amounts of supplemental feeds produce early satiety and discomfort; attempts to increase oral intake are often followed by vomiting. In these circumstances a fine-bore nasogastric tube can be passed and the liquid feed given slowly, at night. If abdominal distension and vomiting continue, the nasogastric tube can be repositioned in the jejunum by endoscope. The liquid feed used for enteral feeding should be modified to provide adequate daily supplies of vitamins, minerals and trace metals. Patients should still be encouraged to eat whatever food they can. Patients may still experience difficulties with enteral feeding and the volume of feed needed to supply daily requirements may be excessive for those who are fluid intolerant. In these circumstances, and in patients incapable of oral or enteral intake, parenteral feeding may be necessary. If some oral or enteral intake is possible, then an estimate should be made of that intake 
and the remaining requirement given parenterally. Difficulty may arise in balancing the diet if there is significant malabsorption, in which case the amount of nutrition given parenterally will have to be determined by trial and error.

Several additional problems arise when providing parenteral nutrition in patients with liver disease. Patients may be fluid intolerant so that the volume infused may need to be restricted to 1 litre or less. It may also be necessary to modify the amino acid solutions used. Recently it has been suggested that amino acid solutions enriched with the branched-chain amino acids (BCAA) leucine, isoleucine and valine might benefit patients with liver disease. Initial trials showed that BCAA-enriched solutions were well-tolerated and appeared to improve nutritional status. Subsequently a number of controlled studies have been undertaken but to date there is no consensus regarding the value of this form of nutritional supplementation in patients with liver disease (Hawley \& Morgan, 1985).

Nutritional support is vital for patients with alcoholic hepatitis. These individuals usually have a long history of alcohol abuse and have generally neglected their diet in the weeks or months before admission to hospital. Quite marked deterioration may occur in their physical condition when hospitalized and this is generally attributed to loss of the energy intake from alcohol. Very little information is available regarding the nutritional requirements of patients with alcoholic hepatitis. It would appear that in these patients, daily protein intakes of up to $30 \mathrm{~g}$ are associated with negative $\mathrm{N}$ balance while daily intakes in the region of 70-100 $\mathrm{g}$ protein ensure positive $\mathrm{N}$ balance (Weber \& Reiser, 1982).

A number of controlled clinical trials of nutritional support in patients with alcoholic hepatitis have been undertaken. Although the results of an early trial were encouraging (Nasrallah \& Galambos, 1980), more recent studies have been disappointing (Calvey et al. 1985; Diehl et al. 1985).

While most authors agree that patients with acute alcoholic hepatitis need additional nutritional support, there is no consensus as to how this might be achieved.

\section{REFERENCES}

Arky, R. A. (1971). In The Biology of Alcoholism, vol. 1, Biochemistry, pp. 197-227 [B. Kissin and H. Begleiter, editors]. New York: Plenum Press.

Arky, R. A. \& Freinkel, N. (1969). In Biochemical and Clinical Aspects of Alcohol Metabolism, pp. 67-80 [V. M. Sardesai, editor]. Springfield: C. C. Thomas.

Badley, B. W. D., Murphy, G. M., Bouchier, I. A. D. \& Sherlock, S. (1970). Gastroenterology 58, 781-789.

Baker, H., Frank, O., Ziffer, H., Goldfarb, S., Leevy, C. M. \& Sobotka, H. (1964). American Journal of Clinical Nutrition 14, 1-6.

Baraona, E., Leo, M. A., Borowsky, S. A. \& Lieber, C. S. (1977). Joumal of Clinical Investigation 60, 546-554.

Baraona, E. \& Lieber, C. S. (1975). Gastroenterology 68, 495-502.

Baraona, E., Orrego, H., Fernandez, O., Amenabar, E., Maldonado, E., Tag, F. \& Salinas, A. (1962). American Journal of Digestive Diseases 7, 318-330.

Barboriak, J. J. \& Meade, R. C. (1970). American Journal of Clinical Nutrition 23, 1151-1153.

Barlow, O. W., Beams, A. J. \& Goldblatt, H. (1936). Journal of Pharmacology and Experimental Therapeutics 56, 117-146.

Bean, W. B., Vitter, R. W. \& Blankenhorn, M. A. (1949). Joumal of the American Medical Association 140, 872-873.

Bebb, H. T., Houser, H. B., Witschi, J. C., Littell, A. S. \& Fuller, R. K. (1971). American Journal of Clinical Nutrition 24, 1042-1052.

Bistrian, B. R., Blackburn, G. L., Vitale, J., Cochran, D. \& Naylor, J. (1976). Journal of the American Medical Association 235, 1567-1570. 
Blackburn, G. L., Bistrian, B. R., Maini, B. S., Schlamm, B. A. \& Smith, M. F. (1977). Journal of Parenteral and Enteral Nutrition 1, 11-22.

Bode, J. Ch., Heidelbach, R., Bode, Ch., Mannheim, W., Durr, H. K. \& Martini, G. A. (1980). In Alcool et Tractus Digestif, INSERM Colloques no. 95, pp. 451-456 [C. Stock and H. Sarles, editors]. Paris: INSERM.

Bollinger, O. (1884). Deutsche Medizinische Wochenschrift 10, 180.

Bretagne, J. F., Lemee, P., Esvant, E. \& Gastard, J. (1982). Semaine des Hopitaux de Paris 58, $575-577$.

Calvey, H., Davis, M. \& Williams, R. (1985). Journal of Hepatology 1, 141-151.

Camilo, M. E., Morgan, M. Y. \& Sherlock, S. (1981). Scandinavian Journal of Gastroenterology 16, $273-279$.

Camilo, M. E. \& Pinto Correia, J. (1982). Revista Portuguesa de Clinica e Terapeutica 7, 43-48.

Castenfors, H., Hultman, E. \& Josephson, B. (1960). Journal of Clinical Investigation 39, 776-781.

Chang, T. \& Glazko, A. J. (1975). In Alcohol and Abnormal Protein Biosynthesis: Biochemical and Clinical, pp. 95-110 [M. A. Rothschild, M. Oratz and S. S. Schreiber, editors]. New York: Pergamon Press.

Chang, T., Lewis, J. \& Glazko, A. J. (1967). Biochimica et Biophysica Acta 135, 1000-1007.

Chowdhury, A. R., Malmud, L. S. \& Dinoso, V. P. (1977). Gastroenterology 72, $37-40$.

Cooke, A. R. (1972). Gastroenterology 62, 501-502.

Crouse, J. R. \& Grundy, S. M. (1984). Journal of Lipid Research 225, 486-496.

Davies, J. P. N. \& Brist, M. B. (1948). Lancet 1, 317-320.

Dastur, D. K., Santhadevi, N., Quadros, E. V. \& Avari, F. C. R. (1976). British Journal of Nutrition 36, 143-159.

Diehl, A. M., Boitnott, J. K., Herlong, H. F., Potter, J. J., Van Duyn, M. A., Chandler, E. \& Mezey, E. (1985). Hepatology 5, 57-63.

Dumont, A. E. \& Mulholland, J. H. (1962). Annals of Surgery 156, 668-675.

Dunlop, W. M., James, G. W. \& Hume, D. M. (1974). Annals of Internal Medicine 80, 740-746.

Eichner, E. R. \& Hillman, R. S. (1971). American Journal of Medicine 50, 218-232.

Fast, B. B., Wolfe, S. J., Stormont, J. M. \& Davidson, C. S. (1959). Gastroenterology 37, 321-324.

Fernandes, G., Nair, M., Onoe, K., Tanaka, T., Floyd, R. \& Good, R. A. (1979). Proceedings of the National Academy of Sciences, USA 76, 457-461.

Frank, O., Luisada-Opper, A., Sorrell, M. F., Thomson, A. D. \& Baker, H. (1971). Experimental and Molecular Pathology 15, 191-197.

Glass, G. B. \& Mersheimer, W. L. (1960). American Journal of Clinical Nutrition 8, $285-292$.

Gottfried, E. B., Korsten, M. A. \& Lieber, C. S. (1976). Gastroenterology 70, 890.

Gray, J. P., Hoyumpa, A. M., Dunn, G. D., Henderson, G. I., Wilson, F. A. \& Swift, L. L. (1980). In Alcool et Tractus Digestif, INSERM Colloques no. 95, pp. 469-476 [C. Stock and H. Sarles, editors]. Paris: INSERM.

Greenberg, L. A. (1970). Quarterly Journal of Studies on Alcohol Suppl., 5, 1-5.

Halsted, C. H., Robles, E. A. \& Mezey, E. (1971). New England Journal of Medicine 285, 701-706.

Halsted, C. H., Robles, E. A. \& Mezey, E. (1973). Gastroenterology 64, 526-532.

Harichaux, P., Lienard, J., Capron, J.-P., Freville, M. \& Moline, J. (1971). Therapie 26, 1039-1048.

Hawley, K. E. \& Morgan, M. Y. (1985). Current Opinion in Gastroenterology 1, 409-417.

Hell, D. \& Six, P. (1977). Deutsche Medizinische Wochenschrift 102, 962-966.

Hift, W. \& Adams, E. B. (1963). Transactions of the Royal Society of Tropical Medicine and Hygiene 57, 445-447.

Higgins, H. L. (1917). Journal of Pharmacology and Experimental Therapeutics 9, 441-472.

Hines, J. D. (1969). British Journal of Haematology 16, 87-101.

Hoyumpa, A. M. Jr, Breen, K. J., Schenker, S. \& Wilson, F. A. (1975). Journal of Laboratory and Clinical Medicine 86, 803-816.

Iber, F. L. (1971). Gastroenterology 61, 120-123.

Israel, Y., Valenzuela, J. E., Salazar, I. \& Ugarte, G. (1969). Journal of Nutrition 98, 222-224.

Jhangiani, S. S., Agarwal, N., Holmes, R., Cayten, C. G. \& Pitchumoni, C. S. (1985). Gastroenterology 88, 1668.

Kalbfleisch, J. M., Lindeman, R. D., Ginn, H. E. \& Smith, W. O. (1963). Journal of Clinical Investigation 42, 1471-1475.

Kesteloot, H., Roelandt, J., Willems, J., Claes, J. H. \& Joossens, J. V. (1968). Circulation 37, $854-864$.

Klipstein, F. A. \& Lindenbaum, J. (1965). Blood 25, 443-456.

Krasner, N., Cochran, K. M., Russell, R. I., Carmichael, H. A. \& Thompson, G. G. (1976). Gut 17, $245-248$.

Krasner, N., Cochran, K. M., Thompson, C. G., Carmichael, H. A. \& Russell, R. I. (1974). Gut 15, 831-832. 
Leevy, C. M., Baker, H., tenHove, W., Frank, O. \& Cherrick, G. R. (1965). American Journal of Clinical Nutrition 16, 339-346.

Leevy, C. M., Valdellon, E. \& Smith, F. (1971). In Biological Basis of Alcoholism, pp. 365-382 [Y. Israel and J. Mardones, editors]. New York: Wiley.

Leevy, C. M. \& Zetterman, R. K. (1975). In Alcohol and Abnormal Protein Biosynthesis: Biochemical and Clinical, pp. 3-15. [M. A. Rothschild, M. Oratz and S. S. Schreiber, editors]. New York: Pergamon Press.

Lieber, C. S., Jones, D. P. \& DeCarli, L. M. (1965). Journal of Clinical Investigation 44, $1009-1021$.

Lindenbaum, J. \& Lieber, C. S. (1969). Nature 224, 806.

Losowsky, M. S. \& Walker, B. E. (1969). Gastroenterology 56, 589-600.

McDonald, J. T. \& Margen, S. (1979). American Journal of Clinical Nutrition 32, 823-833.

Mcllwain, H. \& Bachelard, H. S. (1971). In Biochemistry and the Central Nervous System, 4th ed., pp. 266-307 [H. Mcllwain, editor]. Edinburgh: Churchill Livingstone.

Marin, G. A., Clark, M. L. \& Senior, J. R. (1969). Gastroenterology 56, 727-736.

Mayoral, L. G., Tripathy, K., Garcia, F. T., Klahr, S., Bolanos, O. \& Ghitis, J. (1967). American Journal of Clinical Nutrition 20, 866-883.

Mekhjian, H. S. \& May, E. S. (1977). Gastroenterology 72, 1280-1286.

Mendeloff, A. I., Kramer, P., Ingelfinger, F. J. \& Bradley, S. E. (1949). Gastroenterology 13, $222-234$.

Mendenhal, C. L., Anderson, S., Weesner, R. E., Goldberg, S. J., Crolix, C. A. and the Veterans Administration Cooperative Study Group on Alcoholic Hepatitis (1984). American Joumal of Medicine 76, 211-222.

Mezey, E., Jow, E., Slavin, S. E. \& Tobon, F. (1970). Gastroenterology 59, 657-664.

Mills, P. R., Shenkin, A., Anthony, R. S., McLelland, A. S., Main, A. N. H., MacSween, R. N. M. \& Russell, R. I. (1983). American Joumal of Clinical Nutrition 38, 849-859.

Minot, G. R., Strauss, M. B. \& Cobb, S. (1933). New England Journal of Medicine 203, 1244-1249.

Morgan, A. G., Kelleher, J., Walker, B. E. \& Losowsky, M. S. (1976). Gut 17, 113-118.

Morgan, M. Y. (1981). Acta Chirurgica Scandinavica Supplementum \$07, 81-90.

Morgan, M. Y., Camilo, M. E., Luck, W., Sherlock, S. \& Hoffbrand, A. V. (1981). Clinical and Laboratory Haematology 3, 35-44

Morgan, M. Y. \& Sherlock, S. (1977). British Medical Joumal 1, 939-941.

Mott, C., Sarles, H., Tiscomia, O. \& Gullo, L. (1972). American Joumal of Digestive Diseases 17, $902-910$.

Nasrallah, S. M. \& Galambos, J. T. (1980). Lancet H, 1276-1277.

Neville, J. N., Eagles, J. A., Samson, G. \& Olsen, R. E. (1968). American Joumal of Clinical Nutrition 21, 1329-1340.

O'Keefe, S. J., El-Zayadi, A. R., Carraher, T. E., Davis, M. \& Williams, R. (1980). Lancet H, $615-616$.

Olsen, A. Y. (1950). American Journal of Medical Sciences 220, 477-484.

Owen, O. E., Reichle, F. A., Mozzoli, M. A., Kreulen, T., Patel, M. S., Elfenbein, I. B., Golsorkhi, M., Chang, K. Y. H., Rao, N. S., Sue, H. S. \& Boden, G. (1981). Journal of Clinical Investigation 68, 240-252.

Owen, O. E., Trapp, V. E., Reichard, G. A. Jr, Mozzoli, M. A., Moctezuma, J., Paul, P., Skutches, C. L. \& Boden, G. (1983). Journal of Clinical Investigation 72, 1821-1832.

Paine, C. J., Eichner, E. R. \& Dickson, V. (1973). American Joumal of the Medical Sciences 266, $135-138$.

Patek, A. J. Jr \& Post, J. (1941). Joumal of Clinical Investigation 20, 481-505.

Patek, A. J. Jr, Toth, I. G., Saunders, M. G., Castro, G. A. M. \& Engel, J. J. (1975). Archives of Internal Medicine 135, 1053-1057.

Pirola, R. C. \& Davis, A. E. (1970). Australasian Annals of Medicine 19, 24-29.

Pirola, R. C. \& Lieber, C. S. (1972). Pharmacology 7, 185-196.

Reynolds, T. B., Redeker, A. G. \& Kuzma, O. T. (1965). In Therapeutic Agents and the Liver, pp. 131-142 [N. McIntyre and S. Sherlock, editors]. Philadelphia: F. A. Davis.

Robles, E. A., Mezey, E., Halsted, C. H. \& Schuster, M. M. (1974). Johns Hopkins Medical Journal 135, 17-24.

Roggin, G. M., Iber, F. L., Kater, R. M. H. \& Tobon, F. (1969). Johns Hopkins Medical Joumal 125, 321-330.

Rothschild, M. A., Oratz, M., Zimmon, D., Schreiber, S. S., Weiner, I. \& Van Caneghem, A. (1969). Journal of Clinical Investigation 48, 344-350.

Rubin, E. \& Lieber, C. S. (1968). New England Journal of Medicine 278, 869-876.

Rubin, E., Rybak, B. J., Lindenbaum, J., Gerson, C. D., Walker, G. \& Lieber, C. S. (1972). Gastroenterology 63, 801-814. 
Small, M., Longarini, A. \& Zamcheck, N. (1959). American Journal of Medicine 27, 575-585.

Stinson, J. C. Jr, Baggenstoss, A. H. \& Morlock, C. G. (1952). American Journal of Clinical Pathology 22, $117-126$.

Stock, M. J. \& Stuart, J. A. (1974). Nutrition and Metabolism 17, 297-305.

Tennent, D. M. (1941). Quarterly Journal of Studies on Alcohol 2, 271-276.

Thomson, A. D., Baker, H. \& Leevy, C. M. (1970). Journal of Laboratory and Clinical Medicine 76, 34-45.

Tomasulo, P. A., Kater, R. M. H. \& Iber, F. L. (1968). American Journal of Clinical Nutrition 21, 1341-1344.

Varro, V., Jung, I., Szarvas, F., Csernay, L., Savay, G. \& Okros, J. (1967). American Journal of Digestive Diseases 12, 46-59.

Victor, M. \& Adams, R. D. (1961). American Journal of Clinical Nutrition 9, 379-397.

Vlahcevic, Z. R., Buhac, I., Farrar, J. T., Bell, C. C. Jr \& Swell, L. (1971). Gastroenterology 60, 491-498.

Waters, A. H., Morley, A. A. \& Rankin, J. G. (1966). British Medical Journal Hi, 1565-1568.

Weber, F. L. \& Reiser, B. J. (1982). Digestive Diseases and Sciences 27, 103-110.

Weishaar, R., Sharma, J. S. M., Maruyama, Y., Fischer, R., Bertuglia, S. \& Bing, R. J. (1977). American Journal of Cardiology 40, 556-562.

Whitehead, T. P., Clarke, C. A. \& Whitfield, A. G. W. (1978). Lancet i, 978-981.

Wilson, F. A. \& Hoyumpa, A. M. Jr (1979). Gastroenterology 76, 388-403.

Wood, G. B. (1855). A Treatise on the Practice of Medicine, vol. 2, pp. 168. Philadelphia: Lippincott.

World, M. J., Ryle, P. R., Jones, D., Shaw, G. K. \& Thomson, A. D. (1984). Alcohol and Alcoholism 19, 281-290. 